\title{
УЧЕНИЕ ОБ ИДОЛАХ $Ф$. БЕКОНА И СОВРЕМЕННАЯ КРИТИКА ИДЕОЛОГИИ
}

\author{
Б.Д. Голованов
}

Когда ставят рядом два слов «идеология» и «метод», то в промежутке между ними, закрываемом союзом «и», оказывается целая эпоха становления науки Нового времени. Начинается она методологическими размышлениями Ф. Бекона и заканчивается учением о происхождении идей Дестюта де Траси и коммунистической доктриной К. Маркса. В своем историческом развитии научный метод так или иначе вынужден был преодолевать идеологические границы. Идеология представала либо как религиозное табу на те или иные научные теории, либо как политическое давление государственных и партийных структур на представителей науки, либо как коммерческая заангажированность научных исследований. В постсоветских странах практически невозможно найти политически независимые социологические исследования, а если таковые обнаруживаются, то в большинстве своем они имеют коммерческую подоплеку. Если идеологии прошлого апеллировали к «общественному благу» и искали «истинньх» революционеров и патриотов, осуществлявших это благо, то создатели современных политтехнологий на переднем плане манипулируют общественным мнением, а на заднем плане подсчитывают прибыль от того или иного баланса голосов, которого можно достичь на выборах.

Судьбы идеологии и науки в современном мире прямо противоположны. Достижения науки заполняют страницы школьных учебников и становятся аксиомами общественного мнения, тогда как ошибки, допущенные идеологами, служат страшилками для последующих поколений. Тем не менее идеологические доктрины не перестают появляться, а в социальных науках они образуют почву, из которой растет дерево 
общезначимых истин и общепринятых щенностей. Если мы обратимся к истокам европейской науки, то у ее отцов-основателей найдем рассуждения о том, каким образом следует избегать давления общественных предрассудков и выводить научное исследование на путь истинного познания.

Бекон Веруламский - основатель индуктивного метода утверждал, что прежде, чем наш разум твердо станет на стезю научного познания, необходимо по крайней мере указать причины его отклонения от истины. Эти причины он назвал «идолами» или «призраками». Слово «idola» древнегреческого происхождения («эйдола» - уменьшительное от слова «эйдос» - «вид»), этим словом Гомер называл тени, или души, умерших в царстве Аида. По преданию эти призраки иногда появлялись в мире людей и искажали их сознание. Именно такое истолкование «идола» лежит в основе изречения «мертвый хватает живого».

Термин «идолы» Бекон заимствовал у Эпикура, который «живыми идолами» называл богов. С точки зрения древнегреческого философа эти живые идолы ни злы, ни добры, их невозмутимость и беспристрастность поддерживают порядок мироздания. Однако толпа наделяет богов своими страхами и заблуждениями. Эти страхи и заблуждения создают почву для официальных религиозных верований, эксплуатирующих народное невежество. Высшая задача философа, считал Эпикур, - освободиться от мнения толпы, выйти из-под влияния собственных страстей и «жить, не зная смятения».

Бекон, будучи сыном своего времени, пытается соединить философские поиски истины с христианской критикой веры в языческих божеств и народных суеверий. Он придает слову «идол» значение искажающего фактора, который выступает как препятствие на пути научного познания. Правильно проведенная критика идолов ( демонов» человеческой души) освобождает путь для истинного познания. Бекон пишет о многочисленных, невидимых для обыденного сознания призраках, «которые осаждают умы людей». Он подразделяет их на виды и называет «первый вид идолами рода, второй - идолами пещеры, третий - идолами площади и четвертый идолами театра» ${ }^{1}[2$, c. 18$]$.

Внутри приведенной классификации он проводит еще одно деление идолов на приобретенных и врожденных. «Приобретенные - пи-

\footnotetext{
${ }^{1}$ Соотечественник Френсиса Бекона - Роджер Бекон (ХІІІ в.) также писал о 4$\mathrm{x}$ препятствиях уводяпих познание с пстинного пута: доверие недостаточному авторитету, прнвычка, прнверженность общепрннятым мнениям, боязнь признаться в собственном незнании.
} 
шет Бекон, - вселились в умы людей либо из мнений или учений философов, либо из превратных законов доказательств. Врожденные же присущи природе самого разума, который оказывается гораздо более склонен к заблуждениям, чем чувства. [...] Первые два рода идолов искоренить трудно, а эти последние вовсе невозможно. Остается только одно: указать их, отметить и изобличить эту враждебную уму силу» $[1$, c. 77$]$.

Современные авторы полагают, что среди названных Беконом препятствий познания можно обнаружить те, которые имеют психологические и логические свойства, и те, которые обладают идеологическими свойствами (см. [3, с.29]). На наш взгляд, идолы рода имеют логические свойства, понимание этих идолов идет через указание на логические категории; идолы пещеры выявляются как психологические особенности людей; идолы театра базируются на философских и идеологических доктринах, идолы рынка обнаруживаются как социально-психологические и лингвистические искажения человеческого мышления.

Идолы рода коренятся в природе человеческого ума, который «уподобляется неровному зеркалу, которое примешивает к природе вещей свою природу, отражает вещи в искривленном обезображенном виде» $[2$, с. 19]. Бекон формулирует альтернативу диалектической теории познания Платона, который конечный пункт и идеал познания видел в божественном разуме. Бекон исходит из реальных проявлений человеческого разума, который далек от божественного и своей подпочвой имеет энергию страстей и заблуждений. «Человеческий разум - пишет он, - не сухой свет, его окропляет воля и страсти, а это порождает в науке желательное каждому» $[2$, с. 22].

Обычный человеческий ум, не склонный к научному исследованию, предпочитает верить привычному и общепринятому, нежели через собственный опыт искать истину. Отсутствие терпения останавливает его перед трудностями, он не желает трезво взглянуть на положение вещей, поскольку трезвый взгляд уничтожает призрачную, но сладостную надежду на лучшее. Человеческий ум боится открыться высшей истине и предпочитает иметь дело с суевериями, свет опыта он отвергает «из-за надменности и презрения», от парадоксов он бежит, предпочитая общепринятые мнения. «Бесконечным числом способов пишет Бекон, - иногда незаметных, страсти пятнают и портят разум» $[2, \mathrm{c.} 22]$.

По мнению философа, в наибольшей степени запутанность и заблуждения человеческого ума происходят от косности, несоответствия и 
обмана чувств, ибо то, что возбуждает чувства, предпочитается тому, что сразу чувства не возбуждает, хотя бы это последнее и было лучше. [...] Поэтому все движение духов, заключенных в осязаемых телах, остается скрытым и недоступным людям» [2, с. 22-23]. Сила чувств настолько искажает человеческое созерцание, что ум не в состоянии уловить тонкие движения присущие осязаемым вещам. Однако без исследования и выявления движения мельчайших частиц образующих тела «нельзя достичь ничего значительного в природе в практическом отношении» $[2$, с. 23$]$.

Второй вид заблуждений - согласно Бекону - это «идолы пещеры», которые вызываются индивидуальными особенностями развития человека, так или иначе ограничивающими его мышление. Этот термин Бекон взял из седьмой главы книги Платона «Государство». Символом пещеры древнегреческий философ обозначает всю совокупность препятствий на пути развития человеческого ума. Общие для всех людей препятствия на пути познания, неразрывно связаны с индивидуальными особенностями каждого человека, со своеобразием его положения в общей «пещере». Это своеобразие настолько устойчиво, что можно считать, что каждый индивид сидит в своей собственной пещере. Истина - по описанию Платона - едина и божественна, неразумие каждого человека индивидуально.

«Идолы пешеры, - считал Бекон, - происходят из присущих каждому человеку свойств как души, так и тела, а также из воспитания, из привычек и случайностей» $[2$, с. 24]. На пути познания каждый человек решает индивидуально сформулированные задачи. Индивидуальных искажений не могут избежать даже философы и ученые, посвящающие свою деятельность исследованию общих вопросов познания. Созданные ими теории искажаются предшествующими всякому теоретическому исследованию практическими интересами и желаниями. Бекон выявляет призраки пещеры у такого научного авторитета античности как Аристотель, «который свою натуральную философию совершенно предал своей логике и тем сделал ее сутяжной и почти бесполезной. Химики также на немногих опытах в лаборатории основали свою фантастическую и малопригодную философию. Более того, Гильберт после усердных упражнений в изучении магнита тотчас придумал философию, соответствующую тому, что составляло для него преобладающий интерес» [2, с. 24].

Для борьбы с идолами пещеры нужна, по мнению Бекона, осмотрительность в созерцаниях. Он пишет: «Пусть каждый созерцаюший природу вещей считает сомнительным то, что особенно захватило и 
пленило его разум. Необходима большая предосторожность в случаях такого предпочтения, чтобы разум остался уравновешенным и чистым» $[2$, с. 25$]$.

K следующему роду идолов относятся заблуждения, проистекающие из особенностей совместной жизни людей. Необходимость совместного проживания актуализирует проблему общения и коммуникации. Идолов, гнездяшихся в дефектах социальной коммуникации, философ назвал «идолами рынка (idola fori)». Эти призраки возникают из давления на умы людей языка, с помощью которого они высказывают и формулируют свои мысли. «Люди верят, что их разум повелевает словами. Но бывает и так, что слова обращают свою силу против разума. Это сделало науки и философию софистическими и бездейственными» $[2$, с. 25]. Бекон указывает на то, что большая часть слов нашего языка создана для обслуживания повседневной коммуникации людей, в своих значениях они несут груз эмоциональных и интеллектуальных искажений нашей повседневной жизни.

Естественный язык, когда мы пытаемся использовать его для целей познания, требует очищения от запечатлевшихся в нем чувственных неясностей и двусмысленностей. Озабоченный чистотой научного языка, Бекон отмечает неизбежность вторжения элементов одного уровня познания в структуры другого уровня. В этой связи он пишет: «Большая же часть слов имеет своим источником обычное мнение и разделяет вещи в границах, наиболее очевидных для разума толпы. Когда же более острый разум и более прилежное наблюдение хотят пересмотреть эти границы, чтобы они более соответствовали природе, слова становятся помехой» $[2$, с. 25$]$.

Идолы, навязанные разуму словами, бывают двух разновидностей. Первая из них - полагает Бекон - это «имена несуществующих вещей» $[2$, с. 26$]$. К ним относятся слова, обозначающие вымыслы их авторов. Это своего рода слова-пустышки, исчезающие как только мы обращаемся к опыту. Выдуманные для удовлетворения сиюминутных нужд авторов - эти идолы разоблачаются вместе с устаревшими теориями.

Другая разновидность идолов рынка более трудна для искоренения. Она возникает в результате образования «плохих и неумелых абстракций». Слова, соответствующие таким абстракциям, часто соединяют в своих значениях процессы прямо противоположного характера. Они указывают на действия «которые не допускают никакого объединения или сведения» $[2$, с. 26]. Философ предлагает критически отнестись к многообразию значений таких слов и отбросить те, которые 
не имеют строгих определений. Как полагают некоторые исследователи, Бекон, намечая программу критики «идолов рынка», «поставил ту проблему философии языка, которая ныне занимает внимание многих лингвистов, логиков, кибернетиков, психологов и философов, проблему лингвистического отчуждения и его преодоления» [3, с. 32]. Последователи беконовской методологии в XX веке создали систему методов очистки языка науки от метафизических и идеологических наслоений. Усилиями Р. Карнапа и Л. Витгенштейна была начата исследовательская программа построения логически выверенного универсального языка науки, независящего от субъективных предпочтений исследователя.

Последнюю группу идолов Бекон назвал и «идолами театра», они сопутствуют созданию научных теорий и философских доктрин. Он сравнивает существующие философские системы с театральными спектаклями, представляюшими вымышленные и искусственные миры. Английский философ отдает должное силе и богатству воображения авторов этих систем, но полагает, что на пути к истине воображение должно быть обуздано правильным методом, который оттачивает остроту и точность ума. «Подобно тому, - пишет он, - как для проведения прямой линии или описания совершенного круга много значат твердость, умелость и испытанность руки, если действовать только рукой, - мало или совсем ничего не значит, если пользоваться циркулем и линейкой. Так обстоит и с нашим методом» [2, с. 22].

Примечательно, что Бекон уделяет внимание социально-политическим аспектам распространения философских концепций. Он отмечает, что если бы «гражданские власти, особенно монархические, не противостояли такого рода новшествам, пусть даже умозрительным, и, обращаясь к этим новшествам, люди не навлекали на себя опасность и не несли ущерба в своем благосостоянии, не только не получая наград, но еще и подвергаясь презрению и недоброжелательству, то, без сомнения, были бы введены еще многие философские и теоретические школы, подобные тем, которые некогда в большом разнообразии процветали у греков» $[2$, с. 28$]$.

Возникновению идолов театра полагал Бекон способ́ствует прежде всего искажения и перекосы в проведении научных доказательств и обоснований. За названием «идолы театра» скрываются принципиальные дефекты философских методологий. Эти искажения приводят к появлению трех разновидностей методологических ошибок.

Первая разновидность предстает перед нами в таком гносеологическом феномене как софистика. Софистические призраки возникают 
когда «философы рацноналистического толка выхватывают из опыта разнообразные и тривиальные факты, не познав их точно, не изучив и не взвесив прилежно. Все остальное они возлагают на размышления и деятельность ума» $[2$, с. 28$]$.

Другая разновидность призраков театра, которую Бекон именовал эмпирической, происходит из догматизации выводов, сделанных на основе ограниченного опыта. Приверженцы этой методологии превращают частные эмпирические закономерности в универсальные философские принципы и, исходя из них, строят свои воззрения, «удивительньм образом извращая и толкуя все остальное» $[2$, с. 29]. «И вот, такая философия - пишет Бекон, - кажется вероятной и почти несомненной тем, кто ежедневно занимается такого рода опытами и развращает ими свое воображение; всем остальным она кажется невероятной и пустой» $[2$, с. 30$]$.

Третья разновидность «призраков театра» возникает под влиянием слепой веры и почитания ложных авторитетов. Обольщаясь слепой верой, философия смешивается с богословием и преданиями, в результате чего человеческий ум попадает под влияние поэтических и иных вымыслов. «Өту суетность - полагает Бекон, - надо тем более сдерживать и подавлять, что из безрассудного смешения божественного и человеческого выводится не только фантастическая философия, но и еретическая религия» $[2$, с. 31$]$.

Резюмируя свою стратегию очищения научного познания от разнообразных идолов, Бекон пишет, что «все они должны быть отвергнуты и отброшены твердым и торжественным решением, и разум должен быть совершенно освобожден и очищен от них. Пусть вход в царство человека, основанное на науках, будет почти таким же, как вход в царство небесное, «куда никому не дано войти, не уподобившись детям» $[2$, c. 34$]$.

Характеризуя учение об идолах как предпосылку современных концепций идеологии, мы далеки от утверждения, что исследованное Беконом множество препятствий на пути истинного познания тождественно множеству современных идеологических доктрин. Дело не только в том, что современная наука по своему методологическому арсеналу далеко превзошла науку XVII века, не меньшее значение имеют трансформации, происшедшие в структуре общественной жизни и кардинальное изменившие соотношения теории и практики.

Идеологии и соответствующие им концепции появляются тогда, когда наука дорастает до того, чтобы давать ориентиры не только на пути преобразования природы, но и на пути преобразования социальной 
жизни. Идеология - это не просто социологическая и философская теория, а, прежде всего, политическое учение, которое рассматривает любую социальную теорию с точки зрения успешности социальных преобразований. Истина в данном случае выступает вторичной ценностью в сравнении с общественным благом, равенством, справедливостью и т. д.

Большинство современных социально-философских доктрин выступают как идеологии, то есть как системы иллюзорных представлений о действующих социальных факторах. Они изначально распространяются как идеологические, поскольку политические силы превращают заблуждения отдельного философа в идолы коллективного сознания. Участвуя в создании коллективных иллюзий, современные философские доктрины интегрируются в государственный аппарат и иные структуры политического господства (см. [4, с. 140]). Определяя идеологию как сознательно сконструированную коллективную иллюзию, мы выделяем среди четырех родов «идолов», исследованных Беконом, идолы театра и идолы рынка как наиболее близкие к содержанию современного понятия идеологии.

\section{1 Литература}

[1] Бекон Ф. Сочинения в двух томах. Т. 1.-M., 1972.

[2] Бекон Ф. Сочинения в двух томах. Т. 2.- М., 1972.

[3] Нарский Н.С. Западноевропейская философия XVII века.-M., 1974.

[4] Marcuse H. Philosophy and Critical Theory // Negation. Haramonds worth: Penguim Books, 1968.- P. 134-158. 